\title{
Early Devonian scolecodonts from Podolia, Ukraine
}

Hubert Szaniawski and Daniel Drygant

Acta Palaeontologica Polonica 59 (4), 2014: 967-983 doi: http://dx.doi.org/10.4202/app.2012.0120

One of the most fossiliferous and thickest sections of the marine Lower Devonian deposits was, for the first time investigated for the content of polychaete jaws (= scolecodonts). They are represented by elements of five genera and at least nine species but are not abundant and mostly fractured. Only a fraction of the specimens are sufficiently well preserved to allow genus and species-level identification. However, in some of them even the microstructure of the jaw wall can be observed. Over $90 \%$ of the determinable specimens are represented by the jaws of paulinitids which mostly belong to three species known from the Silurian of the Baltic region. Additionally, mochtyellids, atraktoprionids, skalenoprionids and, in the lower part of the sequence, polychaetaspids have been recorded. Two new species are established-Polychaetaspis kozlowskii sp. nov. and Atraktoprion podolicus sp. nov. Status of the genera Oenonites Hinde, 1879 and Kettnerites is discussed. Lectotype of the first is not determinable to the species level, while holotype of the type species of the second is probably missing and not determinable after the original illustration.

Key words: Polychaeta, scolecodonts, taxonomy, Lochkovian, Pragian, Silurian, Devonian, Podolia.

Hubert Szaniawski [szaniaw@twarda.pan.pl], Institute of Palaeobiology, Polish Academy of Sciences, Twarda 51/55, 00-818 Warszawa, Poland; Daniel Drygant [drygant@gmail.com], State Museum of Natural History, National Academy of Sciences of Ukraine, Teatralna 18, Lviv 79008, Ukraine.

This is an open-access article distributed under the terms of the Creative Commons Attribution License (for details please see creativecommons.org), which permits unrestricted use, distribution, and reproduction in any medium, provided the original author and source are credited. 
Far Full text $(900.7 \mathrm{kB})$ ।

${ }_{F}$ Supplementary file $(39.0 \mathrm{kB})$ 